Хоменко М.М.,

д.е.н., професор, завідувач кафедри менеджменту, Кременчуцький національний університет імені Михайла Остроградського

ORCID: 0000-0003-3198-6696

mmhomenko2016@gmail.com

Дорожкіна Г.М.,

к.е.н., доцент кафедри менеджменту,

Кременчуцький національний університет імені Михайла Остроградського

ORCID: 0000-0002-4131-3850

ganna.dorozhkina@gmail.com

Хоменко Л.М.,

к.е.н., доцент кафедри обліку і фінансів,

Кременчуцький національний університет імені Михайла Остроградського

ORCID: 0000-0002-8074-4805

lusy797@ukr.net

\title{
МЕНЕДЖМЕНТ ВИРОБНИЦТВА ПАСАЖИРСЬКИХ ВАГОНІВ ЗА РАЦІОНАЛІЗАЦІЇ СИСТЕМ ЗАБЕЗПЕЧЕННЯ
}

У статті проведена оцінка скорочення різноманітності систем запасів 3 урахуванням відхилень строків поставок у відповідності з підходом «точно в термін». Обтрунтовано, щчо нарощування обсягів виробнищтва $i$ збільшення прибутку на інвестиції обмежується незначними темпами приросту витрат в інноваційну діяльність за стрімкого зростання частки підприємства на ринку пасажсирських вагонів. Зроблено висновок, щзо існуюча організачія прочесу забезпечення, особливо при виробництві нової продукиії, не здатна в необхідному обсязі сприяти ефективній роботі підприємств в умовах гострої конкурениії. Здійснено аналіз факторів скорочення різноманітності систем забезпечення за иільовою функцією сумарних витрат постачання предметів прачі при виробництві пасажирських вагонів в контексті інноваційного розвитку для підвищення комфортності перевезень при загострені конкуренції на ринку залізничних рухомих засобів. Зменшення різноманітності в системі забезпечення запропоновано здійснювати як способом половинного поділу тобто методом дихотомії, так і рачіональною ї̈ організачією.

Задачу календарного планування виробництва та своєчасної поставки споживачам доцільно вирішувати з врахуванням елементу невизначеності рівня випуску в попередній період $i$ кількості тижнів, щзо залишилися до кіния даного планового терміну. Стохастична природа прочесу забезпечення врахована при ефективному оперуванні стратегічним запасом, який створюється на випадок імовірної затримки в поставках. Розглянуто доцільність запровадження у виробництво оптимального числа модифікацій пасажирських вагонів за раціональної продуктивності та мінімізаціі сумарних витрат. Зменшення наднормативних залишків виробничих запасів литва для 
вагонів запропоновано здійснити за рахунок встановлення постійних договірних відносин з постачальниками Кременчуцького промислового району за виконання ними прийнятих зобов'язань. Нарощування продажів пасажирських вагонів, зростання ринкової долі при реалізачії стратегї розвитку підприємства дозволить стабілізувати зростання прибутку протягом тривалого періоду, підвищувати віддачу акціонерного капіталу, здійснювати модернізацію та нове будівництво, придбавати сучасні основні засоби, поповнювати нематеріальні активи.

Ключові слова: виробництво, пасажирський вагон, забезпечення поставок, нормування витрат, управлінські рішення.

Табл. -1 , Літ. -11.

\section{Хоменко Н.М.,}

д.э.н., профессор, заведующий кафедры менеджмента,

Кременчугский национальный университет имени Михаила Остроградского

ORCID: 0000-0003-3198-6696

mmhomenko2016@gmail.com

Дорожкина А.Н.,

к.э.н., доцент кафедры менеджмента,

Кременчугский национальный университет имени Михаила Остроградского

ORCID: 0000-0002-4131-3850

ganna.dorozhkina@gmail.com

Хоменко Л.Н.,

к.э.н., доцент кафедры учета и финансов,

Кременчугский национальный университет имени Михаила Остроградского

ORCID: 0000-0002-8074-4805

lusy797@ukr.net

\section{МЕНЕДЖМЕНТ ПРОИЗВОДСТВА ПАССАЖИРСКИХ ВАГОНОВ В УСЛОВИЯХ РАЦИОНАЛИЗАЦИИ СИСТЕМ ОБЕСПЕЧЕНИЯ}

В статье проведена оценка сокращения системы запасов с учетом отклонений сроков поставок и в соответствии с подходом «точно в срок». Обосновано, что при росте доли предприятия на рынке пассажирских вагонов и наращчвании объемов производства, увеличения прибыли на инвестичии ограничивается незначительными темпами прироста расходов на инновационную деятельность. Сделаны выводы, что в условиях острой конкуренщии существующая организачия прочесса обеспечения, особенно при производстве новой продукиии, не способна в необходимом объеме способствовать эффективной работе предприятия. Осуществлен анализ факторов сокращения разнообразия систем обеспечения по целевой функиии суммарных затрат снабжения комплектующими производства пассажирских вагонов, как составляющей инновационного развития в разрезе повышения комфортности перевозок на рынке железнодорожных подвижных составов. Уменьшение разнообразия в системе обеспечения предложено осуществлять способом половинного деления методом дихотомии и ее рациональной организации.

Задачу календарного планирования производства и своевременной поставки потребителям целесообразно решать с учетом элемента неопределенности уровня 
выпуска за предылущий период и количества дней, оставшихся до кониа запланированного срока. Стохастическая природа прочесса обеспечения учтена при эффективном оперировании стратегическим запасом, который создается на случай возможной задержки в поставках.

Рассмотрена иелесообразность введения в производство оптимального числа модификаций пассажирских вагонов при рациональной производительности и минимизации суммарных затрат. Уменьшение сверхнормативных остатков производственных запасов литья для вагонов предложено осуществить за счет установки постоянных договорных отношений из стабильными поставщииками при выполнении ими принятых обязательств. Наращивание продаж пассажирских вагонов, рост рыночной доли в условиях реализачии стратегии развития предприятия позволит стабилизировать рост прибыли в течении длительного периода, повысить отдачу акционерного капитала, осуществлять модернизацию и приобретать современные основные средства, пополнять нематериальные активы.

Ключевые слова: производство, пассажирский вагон, обеспечения поставок, нормирование затрат, управленческие решения.

Табл. -1 , Лит. -11 .

M. Khomenko,

Doctor of Economic Sciences, Professor,

Head at Department of Management,

Kremenchuk Mykhailo Ostrohradskyi National University

ORCID: 0000-0003-3198-6696

mmhomenko2016@gmail.com

\section{G. Dorozhkina,}

Candidate of Economic Sciences, Associate Professor,

Associate Professor at Department of Management

Kremenchuk Mykhailo Ostrohradskyi National University

ORCID: 0000-0002-4131-3850

ganna.dorozhkina@gmail.com

\section{Khomenko,}

Candidate of Economic Sciences, Associate Professor, Associate Professor at Department of Accounting and Finance

Kremenchuk Mykhailo Ostrohradskyi National University

ORCID: 0000-0002-8074-4805

lusy797@ukr.net

\section{MANAGEMENT OF PASSENGER CARS PRODUCTION IN THE CONDITIONS OF RATIONALIZATION OF LOGISTICS SYSTEMS}

The article estimates the reduction of the inventory system taking into account the deviations of delivery times and in accordance with the approach "just in time". It is substantiated that with the growth of the company's share in the railway car market and the increase in production volumes, the increase in return on investment is limited by the insignificant growth rate of innovation costs. It is concluded that in conditions of fierce 
competition, the existing organization of the supply process, especially in the production of new products, is not able to contribute to the necessary extent of efficient operation of the enterprise. The analysis of factors of reduction of a variety of systems the components target function of total expenses of supply of manufacture of passenger cars as a component of innovative development in the context of increase of comfort of transportations in the market of railway rolling stock is carried out. It is proposed to reduce the diversity in the logistics system by the method of half division by the method of dichotomy and its rational organization.

The task of calendar planning of production and timely delivery to consumers should be solved taking into account the element of uncertainty of the level of production for the previous period and the number of days remaining until the end of the planned period. The stochastic nature of the provisioning process is taken into account in the efficient operation of strategic stock, which is created in the event of a possible delay in deliveries.

The expediency of introducing into production the optimal number of modifications of passenger cars with rational productivity and minimization of total costs is considered. It is proposed to reduce the excess balances of production stocks of casting for wagons by establishing permanent contractual relations with stable suppliers in the performance of their obligations. Increasing sales of railway cars, increasing market share in the implementation of the company's development strategy will stabilize profit growth over a long period, increase return on equity, modernize and acquire modern fixed assets, replenish intangible assets.

Key words: production, passenger car, supply security, cost rationing, management decisions.

Tabl. -4 , Ref. -11 .

Постановка проблеми. Важливою сферою маркетингової діяльності промислового підприємства за організації випуску продукції виступає поставка, закупка та комплектація виробництва. Об'єкти поставки - сировина, матеріали, комплектуючі. Організація процесу забезпечення, особливо при виробництві нової продукції, має виключне значення для ефективної роботи підприємств в умовах гострої конкуренції. Раціональна організація закупок - провідний фактор зниження витрат. Забезпечення виробництва повинно здійснюватися своєчасно і з мінімальними витратами $[1,2]$. За логістичного підходу до управління матеріальними потоками від постачальника через виробника і до споживача, в тому числі на еколого-економічних засадах, необхідно вибрати: процедуру прийняття і обробки вантажу, раціональну систему складування за доцільності іiі створення, оптимальну систему управління запасами $[3,4]$. Для підвищення ефективності матеріально-технічного забезпечення виробництва пасажирських вагонів, як нової вітчизняної продукції, необхідно дослідити проблему скорочення різноманітності систем запасів з урахуванням відхилень строків поставок у відповідності з підходом «точно в термін».

Процес підготовки управлінських рішень для топ-менеджерів необхідно здійснювати 3 урахуванням невизначеності ситуації та змін в економічному середовищі $[5,6]$. Загострення конкуренції в умовах мінливого економічних середовища підвищує ризик функціонування підприємств в любій галузі, а особливо в машинобудуванні. За таких умов переваги мають підприємства, які використовують сучасні засоби маркетингу і чітко уявляють необхідність створення нової або удосконалення існуючої продукції [7, 8]. На етапі трансформаційного розвитку економіки виникає необхідність більш широкого застосування математичних методів при формуванні управлінських рішень, які можуть більш повно відобразити умови 
господарювання і специфіку вітчизняних промислових підприємств, в тому числі вагонобудівних $[9,10]$.

Аналіз останніх досліджень та публікацій. Для вітчизняних виробників машино технічної продукції настав час напруженої конкуренції не тільки на місцевому, але й, особливо, на закордонних ринках. Транснаціональні корпорації успішно просуваються на ринок нашої країни і створюють глобальну конкуренцію. Аналіз останніх публікацій як закордонних [1, 2], так і вітчизняних авторів [3, 4], свідчить, що за таких умов гострої конкуренції колективи машинобудівних заводів промислових центрів машинобудування, в тому числі й Кременчуцького промислового району, повинні добиватися конкурентних переваг шляхом розробки пропозицій, які задовольняють потреби цільових споживачів в більшій мірі, ніж пропозиції конкурентів. Питання формування конкурентних переваг машинобудівних підприємств в умовах подальшої розбудови ринкових відносин, вступу нашої країни до Світової організації торгівлі, загострення конкуренції на ринку машино технічної продукції набувають особливої актуальності та потребують детального дослідження.

Науковці [4, 11] підкреслюють, що для ефективного управління процесами інноваційного розвитку підприємств вітчизняного вагонобудування важливо розробити та постійно удосконалювати систему економічних інструментів для відповідних функціональних підрозділів підприємства. Необхідно узгоджувати суперечливі цілі стосовно завоювання більшої частки ринку, збільшення прибутку та забезпечення високих темпів стійкого економічного розвитку з можливостями їх досягнення на конкретному підприємстві. Формування організаційно-економічного механізму менеджменту стосовно наступального інноваційного розвитку повинно базуватися на принципі орієнтації за використання сучасних способів і сфер реалізації потенціалу промислового підприємства в мінливих умовах зовнішнього середовища. Керівництво підприємства повинно мати чітке уявлення, за рахунок яких джерел фінансових ресурсів реалізується інноваційний шлях розвитку відповідно до визначеної місії та прийнятої мотивації діяльності і в які сфери буде вкладатися капітал. Забезпечення наступального інноваційного шляху розвитку необхідними фінансовими ресурсами за раціоналізації системи забезпечення виступає ключовим моментом в діяльності любого підприємства, а тим більше вагонобудівного заводу.

Мета дослідження. Розробка практичних рекомендацій щодо скорочення різноманітності систем забезпечення за цільовою функцією сумарних витрат постачання предметів праці при виробництві пасажирських вагонів в контексті інноваційного розвитку промисловості.

Виклад основного матеріалу. Збільшення питомої частки виробничих запасів може свідчити як про розширення масштабів діяльності підприємства, так і неефективне управління запасами. В останньому випадку значна частина капіталу заморожується на тривалий час в запасах i, як результат, уповільнюється їх оборотність. Одночасно з цим необхідно вирішувати проблеми ліквідності, псування сировини та матеріалів, збільшення складських витрат, що негативно впливає на рентабельність виробництва. Розрахунок впливу кількісного (К) і вартісного (Ц) факторів на зміну суми запасів (3) по кожному їх виду здійснюється способом абсолютних різниць на початок $\left(\mathrm{K}_{1}\right)$ і кінець $\left(\mathrm{K}_{0}\right)$ періоду:

$$
\Delta 3_{\mathrm{K}}=\left(\kappa_{1}-\kappa_{0}\right) Ц_{0} ; \Delta 3_{\amalg}=\kappa_{1}\left(Ц_{1}-Ц_{0}\right) .
$$


Період оборотності капіталу в запасах $\left(\Pi_{3}\right)$ сировини та матеріалів, час зберігання їх на складі від моменту надходження до передачі у виробництво, визначається наступним чином:

$$
\begin{gathered}
\Pi_{3}=\text { Середнє сальдо по рахункам запасів х дні періоду / Витрачені запаси за } \\
\text { звітний період. }
\end{gathered}
$$

Уповільнення оборотності капіталу в запасах спеціалістами визначається як за рахунок накопичення надлишкових, неходових, залежалих матеріалів, так і в результаті купівлі додаткових запасів з причини очікуваного зростання темпів інфляції та дефіциту $[2,6]$.

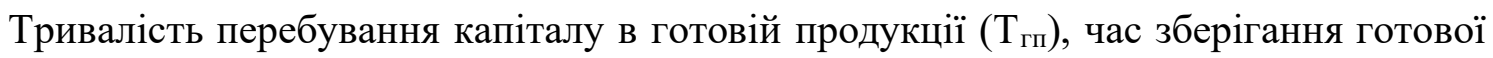
продукції на складах з моменту находження із виробництва до відвантаження покупцям, визначається наступним чином:

$$
\begin{gathered}
\mathrm{T}_{\text {гп }}=\text { Середнє сальдо по рахунку «Готова продукція» } \mathrm{x} \text { дні періоду / Сума } \\
\text { кредитового обороту по рахунку «Готова продукція». }
\end{gathered}
$$

Для аналізу складу, тривалості та причин утворення понаднормативних залишків готової продукції з кожного іiі виду дослідники пропонують користуватися даними аналітичного і складського обліку, інвентаризації та оперативних зведень відділу збуту, служби маркетингу $[2,7]$.

Тривалість виробничого циклу ( $\mathrm{T}_{\text {вц }}$ ), час виробництва продукції, визначається наступним чином:

$$
\begin{gathered}
\mathrm{T}_{\text {вц }}=\text { Середні залишки незавершеного виробництва х дні періоду / Собівартість } \\
\text { випущеної продукції в звітному періоді. }
\end{gathered}
$$

Скорочення виробничого циклу пропонують здійснювати за системного врахування факторів інтенсивності, технології, організації виробництва, матеріальнотехнічного забезпечення та інших $[2,5]$.

Теоретичним і практичним прийомам раціоналізації систем забезпечення та витрачання ресурсів, прогнозування в логістиці присвячена значна кількість досліджень з використанням економіко-математичного моделювання. Значимість прогнозних оцінок удосконалення виробничого процесу та їх практичне використання в управлінні запасами, розробка транспортних та сервісних мереж зазначена в багатьох роботах [7, 10]. Питання раціоналізації систем забезпечення та практичної реалізації методик прогнозних оцінок щодо конкретних параметрів виробничих процесів недостатньо опрацьовані і вимагають додаткових досліджень особливо для умов роботи вітчизняних підприємств.

Обгрунтованість інвестиційних планів підприємства визначається, пер за все, ступенем забезпеченості сировиною, матеріалами та комплектуючими. При вирішенні проблем ефективного управління матеріально-технічним забезпеченням сукупність засобів праці, які утворюють структурні ланцюжки, доцільно перетворювати в кінцевому підсумку в раціональну систему формування заявок на матеріальні ресурси. Особливо гострими $€$ питання забезпечення матеріалами та комплектуючими виробництва сучасних вітчизняних пасажирських вагонів, які раніше в Україні не будувалися. Стохастичний процес поставки широкої номенклатури ресурсів, наприклад матеріалів внутрішнього оздоблення у ПАТ «Крюковський вагонобудівний завод» як виробника широкої номенклатури пасажирських та вагонів метро, є найменш стабільним. 
Перед колективом акціонерного товариства стоїть задача за високої ефективності, найкращих експлуатаційних характеристик, комфортабельності, в поєднанні 3 надійністю конструкції і якістю виготовлення, ідеально сприяти вирішенню проблем, що виникають при виконанні пасажирських перевезень 3 використанням купейних вагонів за прийнятного рівня їх внутрішнього оздоблення. Для задоволення зростаючих потреб споживачів виробники пропонують модифікації пасажирських купейних вагонів, в тому числі СВ та першого класу. Обробка статистичних даних показала, що продуктивність пасажирських купейних вагонів першого класу за місце для сидіння рівномірно розподіляється від 120 до 200 тис. грн. за одне місце в цінах 2019 року [9, 11]. Для умов роботи товариства у відповідності 3 розробленою за нашою участю моделлю обгрунтовується оптимальний ряд випуску пасажирських купейних вагонів за замовленої кількості у відповідному році. Так, вартість виробництва пасажирського купейного вагона першого класу з кількістю місць для сидіння 45 складає $C_{0}=7945$ тис. грн. Для інших модифікацій нової машини (виробу) вартість пропорційна продуктивності пасажирського купейного вагону. Витрати на розробку, випробування і постановку на виробництво нової моделі пасажирського купейного вагону 3 продуктивністю 200 тис. грн. за одне місце $C p$ дорівнює 80000 тис. грн. Величина пропорційності виробництва модифікації пасажирського купейного вагона складає $a$ $=7945$ тис. грн. $/ 45$ місць $=176,5$ грн./місце. Технічні характеристики пасажирських вагонів виробництва заводу наведені в табл. 1.

Місткості купейних вагонів та співвідношення цін

\begin{tabular}{|c|c|c|c|c|c|}
\hline Найменування & Модель & $\begin{array}{c}\text { Пасажирських } \\
\text { купе }\end{array}$ & $\begin{array}{l}\text { Місць в } \\
\text { купе }\end{array}$ & $\begin{array}{l}\text { Місць для } \\
\text { пасажирів }\end{array}$ & $\begin{array}{c}\text { Відпускна ціна, } \\
\text { з ПДВ для } \\
\text { України,\%* }\end{array}$ \\
\hline Купейний вагон & $61-779$ & 10 & 4 & 40 & 100,0 \\
\hline Купейний вагон СВ & $61-779 A$ & 10 & 2 & 20 & 105,5 \\
\hline $\begin{array}{l}\text { Купейний вагон } 1 \\
\text { класу }\end{array}$ & 61-779Б & $11(4 / 7)$ & $6 / 3$ & 45 & 102,5 \\
\hline $\begin{array}{lr}\text { Купейний } & \text { вагон } 1 \\
\text { класу } \quad 3 & \text { купе } \\
\text { бригадира } & \end{array}$ & $61-779 B$ & $10(4 / 6)$ & $6 / 3$ & 42 & 103,0 \\
\hline $\begin{array}{lcr}\text { Вагон } 2 & 2 \text { класу } \\
\text { відкритого типу }\end{array}$ & 61-779Д & - & - & 68 & 95,0 \\
\hline $\begin{array}{l}\text { Вагон } 2 \text { класу } \\
\text { відкритого типу } 3 \\
\text { місцем для інваліда }\end{array}$ & 61-779ДИ & - & - & 60 & 98,5 \\
\hline $\begin{array}{lrr}\text { Вагон } & 2 & \text { класу } \\
\text { відкритого } & \text { типу } \\
\text { баром } & \\
\end{array}$ & $61-779 \mathrm{E}$ & - & - & 30 & 101,5 \\
\hline $\begin{array}{lr}\text { Купейний } & \text { вагон } 3 \\
\text { візками } & \text { нової } \\
\text { конструкщії } & \\
\end{array}$ & $61-779 \mathrm{E}$ & 10 & 4 & 40 & 110,0 \\
\hline Комбінований вагон & $61-788$ & 2 першого класу & 2 & 63 & 107,5 \\
\hline
\end{tabular}

Примітка: * станом на грудень 2019 р.

На підприємстві використовується унікальне устаткування і застосовуються складні системи автоматики для забезпечення встановлених показників якості пасажирських вагонів в широкому асортименті за підвищеної комфортності. Серед пасажирських вагонів сталу позицію на ринку за співвідношенням «ціна-якість» займає модель 61-779. В порівняні із закордонними аналогами конкурентів пасажирський вагон 
цієї моделі має не тільки перевагу за ціною, але є досконалим в силу більшої питомої металомісткості та відповідними технічними характеристиками. Його можна позиціонувати як найбільш доступний вітчизняний виріб за ціною з внутрішнім оздобленням (інтер'єром) напав фабрикатами виробництв Польщі або наукововиробничого об'єднання (НВП) «Комунар» м. Харків.

Маркетингова служба не може з повною упевненістю прогнозувати сумарний обсяг замовлень, які вона отримує на ту або іншу модель пасажирського вагону із семи основних та багатьох модифікацій, що виробляються на підприємстві. Поки персонал підприємства, що здійснює виконання планів поставок відповідних моделей пасажирських вагонів та їх модифікацій за вимогами замовників, підбиває підсумки за минулі $N$ місяців, від споживачів безперервно надходять нові заявки. Виробничі витрати включають не тільки вартість сировини, основних та допоміжних матеріалів, робочої сили, але і витрати на регулювання рівня виробництва на підприємствах. Підприємство буде нести збитки, якщо часто корегуватиме календарний план випуску широкого асортименту пасажирських вагонів 3 урахуванням уточненої інформації відносно сумарного обсягу замовлень, які надходять в продовж кожного місяця. Конкретне підприємство може варіювати рівень виробництва вагонів тільки у відповідних межах. Вони залежать від рівня виробництва в попередній період і кількості тижнів, що залишилися до кінця даного планового терміну. Таким чином, задача календарного планування виробництва та своєчасного відвантаження споживачам містить елемент невизначеності.

Термін «різноманітність» означає загальне число економічного стану виробничої системи або іiі елементу[4, 6]. В нашому випадку елементом виробничої системи виступає забезпечення ресурсами підприємства на всіх етапах функціонування та підготовки до випуску традиційних та нових видів готової продукції. Попит і потреба в продукції багато в чому залежить від перспективності товарного асортименту вагонів за відповідної ціни із значною рентабельністю. При виробництві широкого асортименту вагонів на вхід в систему, тобто підприємство, надходить біля 100 найменувань видів ресурсів і кожне з цих найменувань може перебувати в двох становищах «поступило», «не поступило». Тоді різноманітність підсистеми забезпечення буде дорівнювати: $\mathrm{P}=$ $2^{100}$ становищ $[6,10]$. Основна задача, яка виникає при управлінні такою системою забезпечення полягає у скорочені іiі різноманітності. Показник степені (100) при основі 2 (один біт інформації) показує, скільки поодиноких рішень необхідно прийняти, щоб вибрати прикінцеве рішення.

Зменшення різноманітності в системі здійснюється як способом половинного поділу - метод дихотомії [10], так і раціональною організацією системи. Так, у вагонобудуванні можна виділити три категорії ресурсів, що відносяться до предметів праці: сировина, матеріали і комплектуючі. Відповідно 3 цим, систему забезпечення виробництва вагонів ресурсами, що відносяться до предметів праці, можна навести трьома спеціалізованими напрямками. Вектор ресурсів $\mathrm{X}=\left(\mathrm{x}_{1}, \mathrm{x}_{2}, \ldots, \mathrm{x}_{100}\right)$ ідентифікують три вектори $\mathrm{X}=\mathrm{x}_{1}++\mathrm{x}_{2}+\mathrm{x}_{3}$ :

- сировина $\mathrm{X}_{1}=\left(\mathrm{x}_{1}, \mathrm{x}_{2}, \ldots, \mathrm{x}_{25}\right)$;

- матеріали $\mathrm{X}_{2}=\left(\mathrm{x}_{1}, \mathrm{x}_{2}, \ldots, \mathrm{x}_{50}\right)$;

- комплектуючих $\mathrm{X}_{3}=\left(\mathrm{x}_{1}, \mathrm{x}_{2}, \ldots, \mathrm{x}_{25}\right)$.

Поставка ресурсів здійснюється синхронно 3 виробництвом вагонів. Система «точно у термін» дозволяє не створювати запасів для окремих ресурсів за чіткої роботи постачальників і високої якості матеріалів. Наприклад, поставка комплектуючих 3 ПрАТ «Кременчуцький сталеливарний завод», побудованого в свій час в одній 
технологічній лінії з вагонобудівним, здійснюється чітко за графіком. В такому випадку ресурси, тобто сталеве та чавунне литво, зразу надходять у виробництво. За відсутності технологічної взаємопов' язаності з постачальником така організація забезпечення являє великий ризик для підприємства. Різноманітністю останньої системи неможливо управляти, якщо ресурси поставляються від багатьох постачальників і в більшості випадків не своєчасно. Така ситуація має місце при організації матеріально-технічного забезпечення підприємства 3 виробництва вагонів. Для успішної роботи необхідно уникати появи нерегламентованих простоїв внаслідок відсутності сировини, матеріалів або комплектуючих. Цільова функція сумарних витрат (В) забезпечення предметами праці $[2,4]$ :

$$
\mathrm{B}=\mathrm{C}_{\mathrm{B}}+3_{\mathrm{B}}+Д_{\mathrm{B}} \rightarrow \min ,
$$

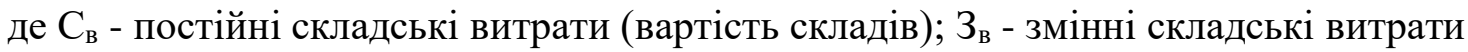
(вартість запасів); Д - дефіцит запасу (витрати обумовлені простоями).

Для ресурсів, які поступають на вхід, необхідно визначити імовірності, що даний ресурс поставляється в строк (становище «поступило»- «1»). По більшості ресурсів дослідним шляхом отримали інформацію щодо провідних постачальників (відстань від постачальника до підприємства, вид транспорту, виконання умов угоди тощо). Процес забезпечення підприємства $є$ стохастичним. За таких умов нормування строків поставок також повинно мати стохастичну основу, тобто строки поставок повинні вказуватися 3 допусками на відхилення, наприклад надходження матеріалів для опорядження пасажирських вагонів 3 Польщі. Довірче значення відхилення ( $\left.\mathrm{P}_{\partial}\right)$ ідентифікує максимальну величину відхилення з вказаною довірчою імовірністю. Частина відхилень 3 імовірністю $\left(1-\mathrm{P}_{\partial}\right)$ може бути і більше вказаного наперед значення відхилення $[2,10]$.

Вирахувавши імовірність поставок кожного виду ресурсу за строками $\mathrm{P}$ $=\left(\mathrm{P}_{1}, \mathrm{P}_{2}, \ldots, \mathrm{P}_{100}\right)$, можна їх розподілити на ті, що поставляються надійними постачальниками, i ті, які поставляються не надійними постачальниками. Для перших імовірність своєчасної поставки більше або дорівнює довірчій імовірності $\mathrm{X}\left(\mathrm{P}>\mathrm{P}_{\partial}\right)$. До других відносяться ресурси, для яких імовірність менше довірчої $\mathrm{X}\left(\mathrm{P}<\mathrm{P}_{\partial}\right)$. Таким чином, для $\mathrm{X}\left(\mathrm{P}>\mathrm{P}_{\partial}\right)$ можна нормувати строки поставок з відхиленнями в сторону запізнення. Відхилення повинні визначатися з врахуванням $\mathrm{P}_{\partial}$. У такому випадку відхилення складають:

$$
\delta=\left(1-P_{\partial}\right) \cdot 100 .
$$

Для сукупності ресурсів $\mathrm{X}\left(\mathrm{P}<\mathrm{P}_{\partial}\right)$, для яких відхилення строків не будуть відповідати фактичному запізненню їх доставки, необхідно створювати запаси і мати склади відповідної місткості. Завдячуючи цим запасам можна скоротити різноманітність системи до $2^{100-\mathrm{k}}$, де $\mathrm{k}$ - кількість різновидів ресурсів, що складуються.

Вся різноманітність системи забезпечення визначається сукупністю ймовірностей своєчасності поставок, які більші або дорівнюють довірчій імовірності X (P > $\left.\mathrm{P}_{\partial}\right)$. Такі ресурси будуть безпосередньо поставлятися на виробництво без створення запасів (наприклад природний газ). Тому зниження різноманітності вирішується, як задача забезпечення строків поставок, що враховують відхилення на $\mathrm{P}_{\partial}$. Якщо цього не врахувати, то можуть виникати виробничі простої обумовлені порушеннями в поставках $\mathrm{X}\left(\mathrm{P}>\mathrm{P}_{\partial}\right)$.

Логічним заходом зниження витрат $(\Delta \mathrm{B})$, що можуть виникнути внаслідок простоїв, буде збільшення виробничого циклу $\left(\mathrm{T}_{\text {ц }}\right)$ на відхилення, що нормується [ $\left.\delta=\left(1-P_{\partial}\right) \cdot 100\right]:$

$$
\Delta B=\left(1-P_{\partial}\right) \cdot T_{u} \cdot 100
$$


На практиці приходиться збільшувати тривалість циклу в сторону більш раннього початку, а не більш пізнього закінчення. Наведемо конкретну виробничу ситуацію, коли підприємство отримало замовлення на виготовлення купейного вагону моделі 61 779 з системою кондиціонування повітря та внутрішнім інтер'єром виробництва НВО «Комунар»(м. Харків) до 10 вересня. Виробничий цикл виготовлення складає 40 днів, то потрібно в ідеальному варіанті починати виготовлення 1 серпня. При врахуванні відхилення $\delta=5 \%, T_{u}=5 \cdot 40 / 100=2$ дні, необхідно розпочати виробничий процес 30 липня.

За рахунок складування ресурсів, для яких відхилення строків не відповідають фактичному запізненню їх доставки, можна зняти невизначеність в системі забезпечення. У цьому випадку необхідно вирішити задачу з визначення величини запасів ресурсів, що складуються. На підприємствах важливо управляти запасами 3 визначенням їх мінімальної, з позицій фінансово-економічних служб, або оптимальної, 3 позицій техніко-технологічних служб, величини і можливих відхилень.

Удосконалення системи забезпечення необхідно здійснювати за використанням прогнозних оцінок стосовно швидкого, частого і гнучкого виконання поставок. Нові поставки на складальні дільниці повинні здійснюватися в потрібний момент. Використання наведеної системи дозволяє суттєво знизити витрати на підтримання запасів і здійснення вантажно-розвантажувальних робіт. Підтримання на мінімальному рівні запасів сировини та матеріалів дає можливість виробникам підвищувати ефективність товароруху за регулярного виконання замовлень споживачів.

Стохастична природа процесу забезпечення вимагає більш ефективного оперування стратегічним запасом, який створюється на випадок імовірної затримки в поставках. Норматив обігових засобів в страхових запасах $\left(3_{\mathrm{i}}\right) i-$ го виду визначається за формулою:

$$
3_{\mathrm{i}}=\Pi_{\mathrm{i}} \times \mathrm{H}_{\mathrm{i}},
$$

де $\Pi_{\mathrm{i}}$ - середньодобова потреба в $i$-тому виді ресурсів; $\mathrm{H}_{i}$ - норма страхового запасу $i$-го ресурсу (в днях).

Норму страхового запасу можна визначити за середнім відхиленням фактичних строків поставок. Ресурс $\mathrm{X}_{\mathrm{i}}$ буде поставлений в строк з врахуванням імовірності $\mathrm{P}_{\mathrm{i}}$, тоді

$$
\mathrm{H}_{\mathrm{i}}=\left(1-\mathrm{P}_{\mathrm{i}}\right) \times \mathrm{T}_{\mathrm{L}} \text {. }
$$

Розрахована норма запасу $\left(\mathrm{H}_{\mathrm{i}}\right)$ буде мінімальною величиною $\left(\mathrm{H}_{\mathrm{i}}^{\mathrm{min}}\right)$, так як при іiі визначені використовується мінімальна тривалість циклу. При розрахунку мінімальної норми запасу необхідно скористатися найбільшою тривалістю циклу, який визначений 3 урахуванням довірчої імовірності

$$
H_{i}^{\max }=\left(1-P_{\partial}\right) \cdot T_{u} .
$$

Ідеальним запасом буде мінімальний, оскільки він вимагає менших грошових вкладень. Разом з тим, складські приміщення необхідно проектувати для максимальної величини запасів.

Висновки. 3 метою підвищення конкуренції пасажирських перевезень 3 боку інших видів транспорту акціонерні підприємства необхідно здійснювати удосконалення конструкцій вагонів у напрямі збільшення швидкості руху та підвищення комфортності за прийнятної ціни рухомого складу. В умовах використання комп'ютерної техніки економічними службами при обгрунтуванні величини страхового запасу сировини, матеріалів та комплектуючих довірчі значення відхилень поставок доцільно визначати за впорядкованими значеннями часових рядів. Запаси поповнювати за необхідності 3 врахуванням надійності постачання та виконання умов договору. 
При удосконаленні управління запасами необхідно використовувати систему $\max$ - min, за якої запаси регулюються - не менше мінімального значення і не більше максимального. Рекомендується розраховувати норми запасів 3 відхиленнями при організації виробництва повного модельного ряду пасажирських вагонів за замовленнями.За впровадження раціональної системи товарно-матеріального забезпечення добиватися високого рівня взаємозамінності основних вузлів для модифікацій пасажирських купейних вагонів авто зчіпними пристроями СА з гумове металевими апаратами Р-5П, що поглинають вібрації, перехідними площадками 3 гумовим огородженням балонного типу. Необхідно створювати комфортні умови проїзду пасажирів і обслуговуючого персоналу шляхом обладнання вагонів різними системами життєзабезпечення: гарячого і холодного водо забезпечення; опалення основного (з електровугільним котлом) та допоміжного (від електрокалориферів системи кондиціонування, низьковольтним опаленням тенами); кондиціонування і вентиляції; освітлення; санітарно-технічним устаткуванням.

\section{СПИСОК ВИКОРИСТАНИХ ДЖЕРЕЛ}

1. Форд Г. Сегодня и завтра. Кодекс миллиардера. Москва: АСТ, 2017. 320 с.

2. Монден Я. «Тойота», методы эффективного управления. Москва: Экономика, 2006. 289 с.

3. Швиданенко Г.О., Криворучкіна О.В., Матукова Д.Г. Розвиток підприємства на еколого-економічних засадах: монографія. Київ: КНЕУ, 2017. 184 с.

4. Павленко А.Ф., Вовчак А.В. Маркетингові стратегії фірми: монографія. Київ: КНЕУ, 2015. 245c.

5. Ферріс Поль У. Маркетингові показники: Більше 50 показників. Які важливо знати кожному керівнику. Київ: Знання, 2017. 480 с.

6. Портер М. Конкурентное преимущество: как достичь высокого результата и обеспечить его устойчивостью. Москва: Альпина Бизнес. Букс, 2015. 715 с.

7. Фатхутдинов Р.А. Конкурентоспособность: экономика, стратегия, управление. Москва: Инфра-М, 2008. 312 с.

8. Шумпетер И.А. Теория экономического развития: капитализм, социализм и демократия. Москва: Эксмо, 2007. 864 с.

9. Дорожкіна Г.М., Хоменко Л.М. Оптимізація ряду модифікацій вагонів-хоперів для зерна і зернових культур. Вісник Хмельнищького начіонального університету: Економічні науки. 2012. № 4 (190). С. 262-269.

10. Лавріненко Н.М., Латинін С.М., Фортуна В.В., Бескровний О.І. Основи економікоматематичного моделювання: навчальний посібник. Львів: Магнолія, 2010. 540 с.

11. Дорожкіна Г.М. Організаційні аспекти інноваційної діяльності підприємств вагонобудування. Вісник Хмельнищького начіонального університету: Економічні науки. 2016. № 5 (228). C. 236-241.

\section{REFERENCES}

1. Ford, G. Segodnya i zavtra. Kodeks milliardera [Today and tomorrow. Billionaire Code]. Mosckow: AST (in Russian)

2. Monden, Ya. «Toyota», metody effektivnogo upravleniya [«Toyota», methods of effective management]. Moscow: Economics (in Russian)

3. Shvydanenko, Gh.O., Kryvoruchkina, O.V., Matukova, D.Gh. (2017) Rozvytok pidpryjemstva na ekologho-ekonomichnykh zasadakh: monoghrafija [Enterprise development on ecological and economic principles:]. Kyiv: KNEU (in Ukrainian) 
4. Pavlenko, A.F., Vovchak, A.V. (2015) Marketynghovi strateghiji firmy: monoghrafija [Marketing strategies of the firm]. Kyiv: KNEU (in Ukrainian)

5. Ferris Polj, U. (2017) Marketynghovi pokaznyky: Biljshe 50 pokaznykiv. Jaki vazhlyvo znaty kozhnomu kerivnyku [Marketing indicators: More than 50 indicators. Which is important for every manager to know]. Kyiv: Knowledge (in Ukrainian)

6. Porter, M. (2015) Konkurentnoe preimushchestvo: kak dostich' vysokogo rezul'tata i obespechit' ego ustoychivost'yu [Competitive advantage: how to achieve a high result and ensure its sustainability]. Moscow: Alpina Business. Books (in Ukrainian)

7. Fatkhutdinov, R.A. (2008) Konkurentosposobnost': ekonomika, strategiya, upravlenie [Competitiveness: economics, strategy, management]. Moscow: Infra-M (in Ukrainian)

8. Shumpeter, I.A. (2007) Teoriya ekonomicheskogo razvitiya: kapitalizm, sotsializm i demokratiya [Economic Development Theory: Capitalism, Socialism, and Democracy]. Moscow: Exmo (in Russian)

9. Dorozhkina, H.M., Khomenko, L.M. (2012) Optymizacija rjadu modyfikacij vaghonivkhoperiv dlja zerna i zernovykh kuljtur [Optimization of a number of modifications of hopper cars for grain and grain crops.]. Visnyk Khmeljnycjkogho nacionaljnogho universytetu: Ekonomichni nauky, no. 4(190), pp. 262-269.

10. Lavrinenko, N.M., Latynin, S.M., Fortuna, V.V., Beskrovnyj, O.I. (2006) Osnovy ekonomiko-matematychnogho modeljuvannja [Fundamentals of economic and mathematical modeling]. Lviv: Magnolia (in Ukrainian)

11. Dorozhkina, H.M. (2016) Orghanizacijni aspekty innovacijnoji dijaljnosti pidpryjemstv vaghonobuduvannja [Organizational aspects of innovative activity of car-building enterprises]. Visnyk Khmeljnycjkogho nacionaljnogho universytetu: Ekonomichni nauky, no. 5(228), pp. 236-241. 